\title{
As doenças como exempla: epidemias e mortes nas cartas do jesuíta José de Anchieta
}

Diseases as exempla: epidemics and deaths in the letters of the Jesuit José de Anchieta

\author{
André Soares Anzolin*
}

\begin{abstract}
Resumo
Este estudo objetiva examinar as interpretações e as construções retóricas desenvolvidas pelo jesuíta José de Anchieta em suas descrições a respeito de casos de doenças que acometeram os Tupinambá da costa atlântica. Para isto, utiliza trechos de correspondências escritas pelo missionário entre os anos de 1556 e 1563. A partir de uma análise discursiva, constata-se que esses relatos, apesar de unânimes em destacar esses fenômenos como manifestações da Providência Divina, diferenciavam-se de acordo com as inclinações que os enfermos apresentavam em receber e praticar os ensinamentos cristãos. Foi possível ainda apontar que a tópica das doenças desenvolvia funções de exemplum nas cartas do missionário, o que lhe permitia exaltar a atuação dos inacianos e, por consequência, realizar a propaganda da missão jesuítica. $\mathrm{O}$ estudo permite compreender como, mesmo tratando de temas funestos, Anchieta logrou construir relatos capazes de gerar experiências devocionais em seus leitores.
\end{abstract}

Palavras-chave: Epidemias. Tupinambá. Missão Jesuítica. José de Anchieta. Retórica.

\begin{abstract}
This study aims to examine the interpretations and rhetorical constructions developed by the Jesuit José de Anchieta in his descriptions of cases of diseases that attacked the Tupinambá of the Atlantic coast. For this, use letters written by the missionary between the years 1556 and 1563. From a discursive analysis, it appears that these reports, despite unanimous in highlighting these phenomena as manifestations of Divine Providence, were distinguished according to the inclinations that the sick had to receive and practice the Christian teachings. On the other hand, it was possible to point out that the topic of disease developed exemplum functions in the missionary letters, which allowed him to exalt the role of the Jesuits, and, consequently, to realize a propaganda of the Jesuit mission. Thus, the study provides insight into how, even when dealing with fateful issues, Anchieta managed to build reports that generate devotional experience for your readers.
\end{abstract}

Keywords: Epidemics; Tupinambá; Jesuitic Mission; José de Anchieta; Rhetoric.

\footnotetext{
* Doutorando em História pela Universidade Federal do Rio Grande do Sul (UFRGS).
}

Recebido em maio de 2015 | Aprovado em janeiro de 2016. 


\section{Introdução}

Na segunda metade do século XVI, quando as epidemias de varíola, sarampo e gripe passaram a vitimar os Tupinambá da costa atlântica, iniciava-se, também, a missão evangelizadora dos padres da Companhia de Jesus na América Portuguesa. Com efeito, o aumento dos contatos com as frentes de conquista proporcionado, de um lado, por expedições militares e "resgates" de índios para o trabalho escravo e, de outro, pela realização dos descimentos e a consequente fixação no interior dos aldeamentos jesuíticos, contribuíram para disseminar uma quantidade significativa de novas enfermidades. Essa interação estimulou contágios e levou ao desenvolvimento de múltiplos surtos epidêmicos ${ }^{1}$ que marcaram definitivamente o primeiro século do encontro entre colonizadores e índios Tupi na costa brasílica ${ }^{2}$. Assim, não é sem razão que os escritos legados pelos primeiros inacianos apresentem diversos relatos e menções sobre o tema, dando conta do choque causado pelas novas enfermidades que afetavam as sociedades indígenas no período quinhentista ${ }^{3}$.

Entre todos os registros produzidos pelos jesuítas, foram, certamente, nas cartas enviadas pelos padres da missão que as descrições sobre as epidemias figuraram com maior recorrência. Nesse contexto, a correspondência enviada pelo jesuíta José de

\footnotetext{
1 “A principal destas doenças hão sido varíolas, as quais ainda brandas e com as costumadas que não têm perigo e facilmente saram; mas há outras que é cousa terrível: cobre-se todo o corpo dos pés a cabeça de uma lepra mortal que parece couro de cação e ocupa logo a garganta por dentro e a língua de maneira que com muita dificuldade se podem confessar e em três, quatro dias morrem; outros que vivem, mas fendendo-se todos e quebra-se-lhes a carne pedaço a pedaço com tanta podridão de matéria, que sai deles um terrível fedor, de maneira que acodem-lhe as moscas como a carne morta e apodrecida sobre eles e lhe põem gusanos que se não lhes socorressem, vivos os comeriam." Carta "Ao Geral Diogo Lainez, de São Vicente, Janeiro de 1565" (ANCHIETA, 1933, p. 238).

2 Dada a ausência de qualquer resistência imunológica dos nativos americanos diante dos novos microorganismos transportados para o Novo Mundo, as epidemias advindas do contato atingiram de forma severa os diferentes grupos indígenas do continente. Na costa da América portuguesa, a pandemia de varíola que, entre os anos de 1562 e 1564, expandiu-se por todas as regiões próximas aos pontos onde se erigiram os povoamentos portugueses foi, possivelmente, a que ocasionou os efeitos mais drásticos entre os Tupinambá. Segundo estimativas da época, somente durante o auge dos contágios (entre dois e três meses), o número de mortos entre índios escravos e forros beirava os 30 mil (ANCHIETA, 1933, p. 356). Neste contexto, a capitania da Bahia, principal frente da missão jesuítica no Brasil, foi também a região mais afetada pela doença. Segundo o Pe. Leonardo Vale, em carta escrita no ano de 1563, a situação na região tornou-se catastrófica. Assim, era normal encontrarem-se casas com mais de 120 enfermos e estimava-se que, nas aldeias de Nossa Senhora da Assumpção, S. Miguel, e Santa Cruz de Taparica, um terço da população havia perecido em dois anos de contágio. Somente em Nossa Senhora da Assumpção, segundo "ouvira dizer" o missionário, computavam-se 1080 mortes. Em outra aldeia da Bahia, chamada Santiago, apenas no mês de abril de 1563, os inacianos batizaram 84 índios "in extremis". Carta "do padre Leonardo do Valle da Bahia para o padre Gonçalo Vaz, provincial da Companhia de Jesus de Portugal”. (AZPILCUETA NAVARRO, 1988, p. 409; 410; 411).

${ }^{3}$ Cabe salientar que este não foi um fenômeno restrito à América Portuguesa ou mesmo às regiões do Novo Mundo, trata-se de verdadeira "unificação microbiana" que atinge, em maior ou menor escala, todas as regiões contatadas pelas frentes coloniais europeias do período das grandes navegações (ALENCASTRO, 2000).
} 
Anchieta tem importância singular. Isto, pois, além de ter permanecido no Brasil de 1553 até sua morte, em 1597, esse missionário ocupava uma posição de destaque no projeto evangelizador desenvolvido entre os índios Tupinambá ${ }^{4}$.

Diferente da maioria dos inacianos que chegaram à América portuguesa, o missionário catalão pouco se ocupou dos cursos ministrados nos colégios inacianos fundados no interior das povoações coloniais. Pelo contrário, realizou uma intensa movimentação entre os estabelecimentos jesuíticos ${ }^{5}$. Preocupado em desenvolver e aplicar estratégias catequéticas entre os índios, Anchieta presenciou os altos índices de mortandade e, em muitos casos, realizou intervenções de cura entre os indígenas enfermos.

Contudo, somente em uma leitura anacrônica, poder-se-ia esperar que a correspondência do missionário utilizasse um tom trágico ao referir-se a eventos que, em poucas décadas, dizimaram os grupos indígenas que ocupavam a costa Atlântica. Obviamente, o discurso adotado pelos inacianos não funcionava como uma transcrição direta da empiria. Longe disso, essas narrativas obedecem a modelos retóricos bem definidos, que só podem ser traduzidos se conhecidos os critérios e as opiniões da recepção europeia no período. Como ressalta João Adolfo Hansen sobre esse aspecto da escrita missionária, os jesuítas " [...] não pensam a nova terra e o gentio que a habita antropologicamente, deve ser óbvio, mas os propõem sempre como o Mesmo, apenas que muito distanciado da boa semelhança católica, segundo a analogia que faz do mundo uma figura do Ditado." (HANSEN, 1995, p. 94).

Com efeito, as cartas apresentam concepções e fórmulas teológico-políticoretóricas que orientam a construção de suas narrativas. Seguindo as perspectivas da filosofia escolástica neo-tomista, os padres da Companhia interpretaram homens, ações e eventos como componentes de uma narrativa já inscrita nas Sagradas Escrituras e nas obras de filósofos e sábios da Antiguidade. Operando de forma analógica, a escrita

\footnotetext{
4 Utilizo o etnônimo "Tupinambá" para designar os diversos grupos Tupi da costa brasileira nos séculos XVI e XVII: Tupinambá propriamente ditos, Tupiniquim, Tamoio, Temiminó, Tupinaé, Caeté etc., que falavam uma mesma língua e participavam da mesma cultura (VIVEIROS DE CASTRO, 2002, p. 186). Quando da chegada dos europeus, esses grupos ocupavam uma extensa faixa territorial ao longo da costa atlântica, desde Iguape (no sul de São Paulo) até o Ceará. O domínio Tupinambá no litoral, contudo, não era contínuo. Assim, outros grupos indígenas (provavelmente Macro Jê) também ocupavam áreas nas "margens do mar", em pontos como o norte do Espírito Santo, o sul da Bahia e a divisa entre Ceará e Maranhão (FAUSTO, 2010, p. 69).

5 Durante a década de 1560, os jesuítas estavam implantados em 6 centros de povoamento português: Salvador da Bahia, Porto Seguro, Espírito Santo, Rio de Janeiro, São Vicente e Piratininga. Na década de 1580 já haviam se estabelecido em outras duas regiões, Olinda em Pernambuco e Ilhéus na Bahia (CASTELNAU-L'ESTOILE, 2006, p. 49-84).
} 
jesuítica tornava-se colonizadora, fazendo do diferente e do outro uma parte do mesmo. Aqui, é importante lembrar as proposições de Michel Foucault a respeito da episteme do século XVI:

O mundo é coberto de signos que é preciso decifrar, e estes signos, que revelam semelhanças e afinidades, não passam, eles próprios, de formas de similitude. Conhecer será, pois, interpretar: ir da marca visível ao que se diz através dela e, sem ela, permaneceria muda, adormecida nas coisas [...].

[...] no tesouro que nos transmitiu a Antiguidade, a linguagem vale como signo. Não há diferença entre essas marcas visíveis que Deus depositou sobre a superfície da Terra, para nos fazer conhecer seus segredos interiores, e as palavras legíveis que os sábios da Antiguidade, esclarecidos por uma luz divina, depositaram nestes livros que a tradição salvou. A relação com os textos é da mesma natureza que a relação com as coisas, aqui e lá são signos que arrolamos. Mas Deus, para exercitar nossa sabedoria, só semeou figuras a serem decifradas (e é neste sentido que o conhecimento deve ser divinatio), enquanto os antigos já deram interpretações que não temos senão que recolher. (FOUCAULT, 2007, p. 44-46).

Foucault acaba por revelar que a hermenêutica do século XVI é essencialmente uma semiologia. Conhecer será interpretar, e os significados, criados à priori por Deus, devem ser descobertos a partir da correta leitura dos sinais que a graça divina depositou - e que não cessam de serem reenviados - no mundo. Dessa forma, as Escrituras constituem parte fundamental da hermenêutica do século XVI. Se os signos eram concebidos como criações divinas, os textos sagrados forneciam a principal fonte de seus significados.

Convictos dessa perspectiva, quando se depararam com as epidemias que abatiam as populações indígenas da costa, os missionários não hesitaram em atribuir suas causas aos desígnios de Deus. Interpretadas à luz das Sagradas Escrituras, as doenças configuravam sinais divinos claros, capazes de ilustrar com eficácia a concepção teológica do período, que tinha como um de seus fundamentos a crença na presença e agência de Deus sobre os seres e as coisas sensíveis ${ }^{6}$. Por essa razão, toda e qualquer doença era concebida como manifestação da Divina Providência ${ }^{7}$.

\footnotetext{
6 "A interpretação cristã das coisas das Escrituras se faz segundo três grandes coordenadas: consideração da presença de Deus nas coisas sensíveis; consideração da presença de Deus nos seres espirituais, almas e puros espíritos; consideração da presença de Deus na alma humana, segundo graus de maior ou menor proximidade na maneira pela qual figuram Deus. A interpretação não se ocupa de meras classificações formais, mas da estrutura mesma do universo e da sua ordem. Como a regra pela qual as coisas se ordenam está escrita na Lei eterna segundo a qual foram criadas, a metafísica da natureza conduz ao fundamento da moralidade. Assim, a interpretação é repetição incansável de um Significado que precede e preforma a história humana com sua Providência." (HANSEN, 2006, p. 92).

7 "Como Providência, entenda-se a manifestação da vontade divina entre os homens, que faz da história uma mobilização eficaz para fazer ver a verdade divina". (SINKEVISQUE, 2011, p. 5).
} 
Os estudos de retórica também fornecem contribuições importantes para a compreensão das preceptivas adotadas nas cartas. Esses trabalhos alertam que as cartas inacianas devem ser compreendidas como "mapas retóricos em progressão", ou seja, como narrações que obedecem a critérios estritos de produção. Como bem destacou Alcir Pécora (1999), é no texto das Constituiciones da Companhia que se encontram as regras da produção discursiva das correspondências jesuíticas. Concebidas como instrumentos da missão catequética, essas cartas possuíam três funções principais: prestar informações, reunir todos os membros da Companhia em uma experiência singular e, ainda, gerar uma experiência devocional entre emissários e destinatários.

Pécora esclarece, ainda, que as cartas jesuíticas do século XVI, seguindo as preceptivas da ars dictamis medieval - ainda que adaptadas por Inácio de Loyola aos objetivos evangelizadores da Companhia - dividiam-se retoricamente em 5 partes: salutatio, captatio benevolentiae, narratio, petitio e conclusio. Na salutatio, era efetuada a repetição de fórmulas piedosas, utilizadas em decoro com as relações hierárquicas de remetentes e destinatários. Na captatio benevolentiale, buscar-se-ia, por meio de procedimentos de escrita, captar uma disposição favorável no leitor da carta. Na narratio, o autor deveria, por meio de uma breve narração, tratar dos temas relevantes para os objetivos da correspondência. Na petitio, tendo em vista o que já fora mencionado, o destinatário solicitaria ao leitor um auxílio com vistas a amenizar as dificuldades encontradas na realização de seus propósitos. Na conclusio, por fim, apresentar-se-iam, rapidamente, os principais temas da carta e, só então, esta se encerraria com uma fórmula apropriada, relacionada à salutatio (PÉCORA, 1999).

Quanto ao gênero, aprendemos com João Adolfo Hansen que as correspondências apresentam informações de caráter familiaris e negotialis, comportando, em alguns casos, a mescla de ambos. Além disso, segundo propõe,

[...] a correspondência também é apropriada e divulgada como epístola - no sentido de Deismann - nos usos e feitos dela em Roma pelos superiores da Ordem, principalmente a partir de 1566 , quando começa a ser vertida ao latim. (HANSEN, 1995, p. 90).

Analisemos, portanto, à luz dessas contribuições, alguns relatos sobre as epidemias nas cartas de Anchieta, a fim de destacar as interpretações teológico-políticas formuladas pelo missionário sobre as causas das doenças, e os usos retóricos dessas narrativas no interior das correspondências. Para isso, foram selecionadas, nas correspondências do jesuíta, trechos de descrições que envolvem casos de enfermidades 
e mortes concebidas de formas distintas: a primeira trata de um episódio de cura de um índio enfermo que fora tratado pelos padres; a segunda abarcará a descrição de um caso de mortandade de índios considerados "contrários" pelos jesuítas; por fim, a análise enfocará um relato de enfermidade e morte de um índio batizado, considerado aliado pelos missionários. Apesar de narrarem eventos singulares de doenças e mortes, as estruturas retóricas e as interpretações formuladas sobre os casos selecionados são representativas e, com algumas variações, replicam-se ao longo das cartas legadas pelo jesuíta.

\title{
Doenças como exempla da providência divina
}

Para iniciar a análise, cabe destacar que, nas cartas de Anchieta que possuem referência a doenças e ao perecimento entre os índios, esses relatos ocupam a parte designada como narratio. Nesse ponto, essas descrições adquirem a função de exemplum, artifício retórico que garantiu um avanço das correspondências jesuíticas em relação às preceptivas da ars dictamis medieval (LUZ, 2003, p.37). Como exemplum, cumprem objetivos essenciais da escrita inaciana: propiciam o desenvolvimento de uma experiência devocional entre emitentes e destinatários ${ }^{8}$ desses escritos, e se tornam veículos de propaganda da atuação dos missionários.

$\mathrm{Na}$ descrição de casos de cura de doenças a partir da intervenção dos padres, as cartas de Anchieta apresentam, entre outros pontos, a exaltação da caridade dos inacianos:

\begin{abstract}
Ao outro dia nos fomos lá mui depressa, para curar o ferido e aparelhá-lo para o batismo, e encontrando-o em caminho, que o traziam a nós outros para que o curássemos, nos tornamos, curamos-lhe as feridas até sarar, e entretanto por remediar as chagas de sua alma o instruímos em os rudimentos da fé. Aprendeu ele de boa vontade, e determina daqui em adeante viver segundo o que Deus manda, de maneira que por mui fera que seja a sua natureza, trabalharemos com todo cuidado para domar, pois não estão cerradas aquelas entranhas de misericórdia, em as quais nos visitou o Senhor nascendo do alto, para que também a estes abra caminho para entrar no tabernáculo do Senhor. (ANCHIETA, 1933, p. 100- 101). ${ }^{9}$
\end{abstract}

\footnotetext{
8 “Composto como função de reconhecimento doutrinário que faz traduções do desconhecido através de um critério teológico e retórico universalmente partilhado, o destinatário é, na carta, personagem sinônimo do "eu" da enunciação, duplicando-o como circularidade de código." (HANSEN, 1995, p. 88).

${ }^{9}$ Carta relativa ao Quadrimestre de setembro até o fim de dezembro de 1556, de Piratininga, abril de 1557.
} 
Ao narrar episódios singulares de sucesso nos tratamentos, o jesuíta produz enunciados apologéticos, que exaltam a doutrina católica e a missão evangelizadora empreendida pelos inacianos. Entre esses, a associação entre a cura e a conversão do enfermo constitui um argumento recorrente. Interpretada à luz do filtro teológicopolítico adotado pelos inacianos, a restauração da saúde do enfermo é diretamente relacionada à sua disposição em receber os ensinamentos cristãos. Uma vez que, para os jesuítas, os tratamentos eram regidos pela ideia de que o abandono dos "maus costumes" ${ }^{10}$ era condição essencial para a obtenção da cura, a saúde dos indígenas e a observância das leis divinas tornavam-se práticas indissociáveis. As lesões que se espalhavam entre os índios que habitavam os aldeamentos jesuíticos eram tratadas como alerta para que eles cuidassem, além dos ferimentos do corpo, das chagas provocadas na alma dos que mantinham uma conduta pecaminosa ${ }^{11}$.

Além disso, o missionário preocupa-se em assinalar que a doença configurava um momento propício à evangelização. Cercado de dores e angústias, o enfermo mostrava maior disposição em adotar a doutrina trazida pelos padres. Dessa forma, Anchieta salienta que a prática caridosa dos tratamentos podia alcançar, para além da tranquilidade de consciência dos padres, o objetivo maior da atuação missionária, que se centrava, obviamente, na conversão dos indígenas.

Registre-se ainda que, ao descrever os cuidados prestados pelos jesuítas, Anchieta esforça-se em ressaltar a atuação caridosa dos inacianos. Para isso, o inaciano destaca a celeridade com que os padres atendiam os enfermos, mesmo quando estes adotavam práticas contrárias à lei natural. Dessa forma, Anchieta põe em relevo o compromisso dos missionários com os fundamentos teológicos propostos pela devotio moderna, que tinha como foco a imitação do exemplo de Cristo ${ }^{12}$. Nesse caso, o modelo que se ambicionava atingir era o do Christus Médicus ${ }^{13}$ pois, como relatam os Evangelhos, "Cristo é um médico: médico do corpo - de que são testemunhas suas

\footnotetext{
${ }^{10} \mathrm{Na}$ América portuguesa, a falta de ídolos entre os Tupinambá levou à crítica dos religiosos para o campo dos costumes. Bestiais, indômitos, carniceiros, selvagens e outros adjetivos foram utilizados para classificar práticas como a antropofagia, o xamanismo, as guerras por vingança, as cauinagens, a poligamia e a nudez que, em suma, foram interpretadas como pecados pelos padres.

${ }^{11}$ Afinal, após o Concílio de Trento, afirmou-se entre a cristandade a ideia de que o pecado não corrompia totalmente a natureza dos homens (HANSEN, 2000).

12 Dessa corrente, a principal influência foi fornecida pela obra De Imitatione Christi, do monge alemão Thomas à Kempis, editada no início do século XV.

13 "Jesus percorria toda a Galiléia, ensinando nas suas sinagogas, pregando o Evangelho do Reino, curando todas as doenças e enfermidades entre o povo; Sua fama espalhou-se por toda a Síria: traziam-lhe os doentes e os enfermos, os possessos, os lunáticos, os paralíticos. E ele curava a todos." (MATEUS, 4, 22-23)
} 
curas miraculosas - médico da alma - já que ele mostrou ao homem o caminho da salvação." (LE GOFF; TRUONG, 2006, p. 109).

Assim, ao se depararem com as enfermidades no Novo Mundo, os "soldados de Cristo" possuíam um exemplo claro a seguir. A realização das curas representava uma atividade apostólica plena: além de seguir o ensinamento da caridade de Cristo, eram capazes de converter aqueles que se mantinham em hábitos pecaminosos. Desse modo, por meio da narração dos casos de cura, Anchieta produz uma propaganda da atuação dos missionários, assinalando que estes agiam como verdadeiros instrumentos de Deus, expandindo seus mandamentos e fornecendo o único caminho possível para a salvação do corpo e da alma dos índios.

Muito distintas eram as interpretações teológico-políticas formuladas a respeito das expansões epidêmicas que afetavam grupos considerados "contrários" pelos inacianos:

\begin{abstract}
Porque se ofereceu fazer menção dos contrarios, direi algumas cousas, não fora de proposito. Veiu, poucos dias ha, grande cópias deles, e combatendo um lugar de Portugueses, o roubou; acolheram-se á fortaleza, sete ou oito Portugueses, que se acharam presentes, e como quisessem entrar com eles os inimigos foram mortos muitos deles; por outra parte acometeram uma casa onde estavam dois Cristãos e saltando como simios no telhado, derribando as telhas, os tomaram por fôrça e levaram com muitos dos escravos e demais prêsa. Não muito depois se seguiu uma peste de que morreu grande número de contrários, tiravam os mortos de casa e deitavam-os ás onças, as quais de noite vinham e os comiam. Desta maneira os castigou a dextra do Senhor [...]. (ANCHIETA, 1933. p. 99).
\end{abstract}

No trecho apresentado, a descrição inicial fornece, àqueles que partilhavam do código retórico e teológico-político do autor ${ }^{14}$, premissas que permitem a compreensão das causas do evento narrado em seguida. Compreendendo o projeto evangelizador como vontade Divina, a conduta dos índios “inimigos” era qualificada como empecilho à expansão da fé, e passava a representar clara ofensa a Deus. Ao agirem como símios, atacando os cristãos, os inimigos contrariavam as leis naturais e, assim, tornavam-se alvos da "dextra do Senhor". Valendo-se de amplo domínio da técnica retórica, Anchieta desenvolve uma construção, na qual o evento epidêmico entre grupos inimigos torna-se exemplum. Este, de um lado, permite ao missionário ressaltar os castigos por meio dos quais a ira Divina pune os injustos e os pecadores e, de outro, confirma a proteção que a Providência dispensa àqueles que, mesmo ameaçados por infiéis,

\footnotetext{
14 "O conhecimento das "coisas naturais", devidamente orientado na perspectiva teológica a lhe fornecer sentido é, portanto, indissociável dos efeitos de deleite a provocarem no leitor devoto". (LUZ, 2003, p. $110)$.
} 
partilham da fé cristã. Diante de uma população "pagã", que apresenta e insiste em manter, em sua conduta, uma alteridade radical em relação aos hábitos cristãos, a erupção de violentas epidemias reiterava a conformidade entre a atuação dos missionários e o projeto divino que, ao punir os índios, dava prova de sua reprovação em relação aos "maus costumes" e à belicosidade indígena.

Os enunciados formulados a respeito do tratamento prestado aos mortos pelos índios contrários também merecem atenção. Ao afirmar que estes "deitavam" os mortos para que fossem devorados pelas onças - prática que, obviamente, não constituía parte dos ritos funerários dos Tupinambá - Anchieta visa imputar hábitos bestiais aos grupos inimigos. Assim, o missionário faz entender que, mesmo após o evento epidêmico que abatera parte do grupo, aqueles que permaneceram vivos continuavam realizando atos de barbárie. Com isso, a intenção do inaciano parece orientar-se a não deixar dúvidas de que a morte dos inimigos configurava nítida ação da justiça Divina.

Destaca-se, ainda, o fato de que, ao referir-se a doenças que acometiam grupos "contrários", Anchieta utiliza-se, sobretudo, do termo peste, categoria que remetia diretamente as punições divinas descritas no texto bíblico. É nesse sentido que o Deuteronômio apresenta, sobre os malefícios a que são submetidos os que não praticam os mandamentos, uma série de itens relacionados às pragas e pestes:

\begin{abstract}
O Senhor mandar-te-á a peste, até que ela te tenha apagado da terra em que vais entrar para possuí-la. O Senhor te ferirá de fraqueza, febre e inflamação, febre ardente e secura, carbúnculo e mangra, flagelos que te perseguirão até que pereças. O Senhor te ferirá da úlcera do Egito, de hemorróidas, de sarna e de dartros incuráveis. O Senhor te ferirá de loucura, de cegueira e de embotamento de espírito. O Senhor te ferirá nos joelhos e nas coxas com uma úlcera maligna e incurável, e que se estenderá da planta dos pés ao alto da cabeça. O Senhor te ferirá, bem como a tua posteridade, com pragas extraordinárias, pragas grandes e permanentes, doenças perniciosas e pertinazes. Fará voltar contra ti todas as enfermidades do Egito que temias, e elas pegarão em ti. Além disso, o Senhor enviará contra ti, até que sejas exterminado, toda sorte de enfermidades e pragas, que não estão escritas no livro desta lei (DEUTERONÔMIO, 28, 21-22;27-28;35;59-61).
\end{abstract}

De fato, é bastante evidente que o texto sagrado constitui a fonte maior de significados entre os homens da cristandade no período quinhentista. Como ressalta Michel Foucault (2007):

A linguagem do século XVI - entendida não como um episódio na história da
língua, mas como uma experiência cultural global - foi sem dúvida tomada
nesse jogo, nesse interstício entre o Texto primeiro e o infinito da
Interpretação. Fala-se sobre o fundo de uma escrita que se incorpora ao
mundo; e sobre ela fala-se infinitamente sobre ela, e cada um de seus signos 
torna-se, por sua vez, escrita para novos discursos; mas cada discurso se endereça a essa primeira escrita, cujo retorno ao mesmo tempo promete e desvia. (FOUCAULT, 2007, p. 57).

Nessa concepção, o signo peste adequava-se perfeitamente à interpretação de epidemias que atingiam indígenas que, de forma reiterada, negavam-se em receber os mandamentos e doutrinas divulgadas pelos padres. Essa categoria permitia, ainda, que o inaciano tratasse de casos de doenças entre índios "contrários" de forma coletiva e, por meio dessa construção retórica, possibilitava ao missionário explorar a ideia de simultaneidade entre esses contágios. Assim, o termo peste ilustrava de maneira clara que, como eram inimigos da evangelização, os índios contrários não tardavam em receber, em conjunto, as punições Divinas.

Contudo, como se sabe, as doenças também vitimaram índios que mantinham boas relações com os inacianos. A descrição da morte de um principal, batizado com o nome cristão de Martin Afonso, demonstra as distâncias nas construções retóricas e teológico-políticas de descrições de enfermidades que atingiam índios contrários e aliados dos inacianos:

\begin{abstract}
Morreu tambem o nosso principal, grande amigo e protetor Martin Afonso, o qual depois de se haver feito inimigo de seus próprios irmãos e parentes, por amor de Deus e da sua Igreja, e depois de lhe haver dado Nosso Senhor vitória de seus inimigos estando ele com grande propositos, e bem determinado a defender a causa dos Cristãos, e a nossa casa de S. Paulo, que bem conhecia ter sido edificada em sua terra por amor dele e de seus filhos, quis dar-lhe Deus o galardão de suas obras, dando-lhe uma doença de camaras de sangue, na qual como não houvesse sinal de melhoria, mandou chamar um Padre que todos os dias o visitava e curava; confessou-se, e no outro dia se tornou a reconciliar com grande sentimento de sua vida passada, e de não haver bem guardado o que lhe havíamos ensinado, e isto fez com tanto senso e madureza que não parecia homem do Brasil. Fez seu testamento, e deixou recomendado á sua mulher e filhos que seguissem as nossas palavras, e em dia da Natividade de N. S. Jesus Cristo morreu, para nascer em vida nova de glória, como esperamos (dezembro 25 de 1562). (ANCHIETA, 1933, p. 187). ${ }^{15}$
\end{abstract}

Semelhante às narrações de doenças e mortes de índios contrários, a descrição do perecimento do índio "cristão" é antecedida por um breve relato dos feitos passados do enfermo. Contudo, nesse caso, o missionário realiza um encômio da conduta do Principal. Para tanto, ressalta o fato de o índio ter contraído a inimizade de seus parentes por ter realizado a defesa constante à "causa dos cristãos".

\footnotetext{
${ }^{15}$ Carta Ao geral Diogo Lainez, de São Vicente, a 16 de abril de 1563.
} 
Com efeito, ao relatar a morte de um índio aliado, que possuía um juízo distante dos demais "homens do Brasil", as causas de sua doença eram interpretadas de forma diametralmente oposta àquelas que afetavam os grupos inimigos. O fato de ter deixado recomendações cristãs a seus familiares, fazendo frutificar a palavra divina, leva o jesuíta a utilizar-se, em sua narrativa, de uma sentença presente na primeira Epístola de São Paulo proferida à Igreja de Corinto que se adequa perfeitamente ao sentido que pretende atribuir ao caso em questão: "Se a obra que alguém edificou nessa parte permanecer, esse receberá galardão.” (I CORINTIOS, 3; 14).

Uma vez que, com muito "senso e madureza", Martin Afonso havia confessado seus pecados "in extremis", o índio não mais pecaria em vida. Esse ato de constrição, aliado ao apoio prestado por Tibiriça ao projeto evangelizador, leva o jesuíta a concluir sua narrativa, afirmando a crença de que o "protetor" dos inacianos alcançaria a vida eterna. Desse modo, a descrição dá a entender que essa liderança havia cumprido os passos necessários para "o bem morrer" de acordo com os princípios da ars moriendi cristã $^{16}$. A enfermidade, nesse contexto, assemelhava-se a uma recompensa de Deus, que reconhecia os benefícios prestados pelo índio "cristão" à evangelização empreendida pelos padres e, sobretudo, possibilitava-o, de uma vez por todas, apagar os pecados de sua “vida passada". Dessa forma, a interpretação teológico-política da causa de seu perecimento aproximava-se sobremaneira daquelas utilizadas pelos padres nas cartas em que referem à morte de portugueses cristãos e religiosos da Companhia. Um exemplo de formulação semelhante pode ser encontrado na narração utilizada por Anchieta ao relatar o falecimento do Pe. Mateus Nogueira; este, contudo, não precisou da caridade de seus Irmãos de Companhia para "bem morrer":

O dia de Janeiro de S. Paulo Eremita, quis Nosso Senhor levar para si o nosso Irmão Mateus Nogueira ferreiro, que era homem de idade, e muito mais velho por suas continuas enfermidades que padecia, em as quais nunca deixava de trabalhar, sendo contínuo na oração, com mui especial zêlo da conversão dêstes Brasis, pelos quais continuamente rogava a Deus, porque ignorando sua lingua não podia prègar: morreu de uma dôr de colica e pedra que muitas vezes padecia, e com que esteve padecendo cinco dias até que deu a alma ao Senhor, conhecendo a sua morte antes de falecer. Não foi

\footnotetext{
16 Philippe Ariès resumiu a concepção da cristandade à época. Segundo o autor, no leito de morte "Deus e sua corte estão presentes para constatar como o moribundo se comportará no decorrer da prova que lhe é proposta antes de seu último suspiro e que determinara sua sorte na eternidade. Esta prova consiste em uma última tentação. O moribundo verá sua vida inteira, tal como está contida no livro, e será tentado pelo desespero pelas suas faltas, pela glória vã de suas boas ações, ou pelo amor apaixonado por seres e coisas. Sua atitude, no lampejo deste momento fugidio, apagará de uma vez por todas os pecados de sua vida inteira, caso repudie todas as tentações, ou, ao contrário, anulará todas as suas boas ações, caso ele venha a ceder. A última prova subtitui o juízo final”. (ARIÈS, 2003, p.52).
} 
necessário acordar a caridadedos Irmãos para rogar a Deus por um homem santo, assim pelos vivos, como pelos mortos. (ANCHIETA, 1933. p. 174). ${ }^{17}$

Por fim, ainda que mais raros, observam-se nas cartas de Anchieta as descrições de casos singulares de doenças que eram tratadas com sucesso pelos inacianos. Nelas, a associação entre a cura e a conversão do enfermo constitui argumento central:

\begin{abstract}
Ao outro dia nos fomos lá mui depressa, para curar o ferido e aparelhá-lo para o batismo, e encontrando-o em caminho, que o traziam a nós outros para que o curássemos, nos tornamos, curamos-lhe as feridas até sarar, e entretanto por remediar as chagas de sua alma o instruímos em os rudimentos da fé. Aprendeu ele de boa vontade, e determina daqui em adeante viver segundo o que Deus manda, de maneira que por mui fera que seja a sua natureza, trabalharemos com todo cuidado para domar, pois não estão cerradas aquelas entranhas de misericórdia, em as quais nos visitou o Senhor nascendo do alto, para que também a estes abra caminho para entrar no tabernaculo do Senhor (ANCHIETA, 1933, p. 100, 101). ${ }^{18}$
\end{abstract}

À luz da percepção político-teológica adotada pelos inacianos, a restauração da saúde dos enfermos é diretamente relacionada à sua disposição em receber os ensinamentos cristãos. Uma vez que, para os jesuítas, os tratamentos eram regidos pela ideia de que o abandono dos "maus costumes" 19 era condição essencial para a obtenção da cura, a saúde dos indígenas e a observância das leis divinas tornavam-se práticas indissociáveis. As chagas que se espalhavam entre os índios que habitavam os aldeamentos jesuíticos eram tratadas como alerta para que estes cuidassem, além dos ferimentos do corpo, das chagas provocadas na alma dos que mantinham uma conduta pecaminosa $^{20}$.

Por meio da narração dos casos de cura, Anchieta realizava um encômio da missão jesuítica. Defendia que a prática caridosa dos tratamentos podia alcançar, para além da tranquilidade de consciência dos padres, o objetivo maior da atuação missionária: a conversão dos indígenas. Para tanto, destacava que, frente à proliferação de enfermidades, os padres da Companhia agiam seguindo o modelo de Cristo,

\footnotetext{
${ }^{17}$ Carta Ao padre Geral Diogo Lainez, de São Vicente, a 12 de junho de 1561.

18 Carta relativa ao Quadrimestre de setembro até o fim de dezembro de 1556, de Piratininga, abril de 1557.

${ }^{19}$ Se em boa parte da América Espanhola a idolatria serviu como tônica da detração dos povos nativos, na América portuguesa, a falta de ídolos entre os Tupinambá levou a crítica dos religiosos para outro campo: o dos costumes. Bestiais, indômitas, carniceiras, selvagens e outras adjetivações foram utilizadas para classificar práticas como a antropofagia, o xamanismo, as guerras por vingança, as cauinagens, a poligamia e a nudez, que, em suma, foram interpretadas como pecados pelos padres.

${ }^{20}$ Afinal, após o Concílio de Trento, afirmou-se entre a cristandade a ideia de que o pecado não corrompia totalmente a natureza dos homens. (HANSEN, 2000).
} 
expandindo seus ensinamentos e fornecendo o único caminho possível para a salvação do corpo e da alma dos índios.

\section{Considerações finais}

Com o exposto, observa-se que as interpretações providencialistas de casos de enfermidade presentes nas cartas anchietanas, apesar de possuírem, nos desígnios divinos, uma Origem comum, diferenciam-se de acordo com a disposição que os índios mostravam em receber e praticar os ensinamentos cristãos. Desse modo, a mesma doença podia ser interpretada, tanto como manifestação da Ira Divina a abater os pecadores quanto como um sinal da benevolência de Deus que, por meio de enfermidades, abria a porta dos céus aos índios conversos. Além disso, elas também poderiam configurar um aviso enviado pela providência àqueles que, mesmo recebendo a mensagem cristã, insistiam em práticas "bestiais".

Evidencia-se também que, nas cartas do missionário, as narrativas de doenças que acometiam os índios foram ajustadas às preceptivas da ars dictamis, ainda que adaptada aos propósitos inacianos. Assim, essa tópica tornou-se exemplum capaz de, por meio da formulação de enunciados com conteúdo apologético da doutrina cristã e da ação caridosa dos inacianos, compor narrativas que exaltavam a conformidade entre a missão jesuítica e os desígnios divinos. Com efeito, parece confirmar-se, nesses casos, o que propõe Guilherme Amaral Luz ao sustentar que “[...] a História deve ser pensada, no caso jesuítico, como um instrumento retórico de propaganda, o que, na tradição do gênero, é possibilitado pela figura do exemplum." (LUZ, 2003, p. 110).

Nesse contexto, apesar das distâncias que marcam os trechos selecionados, pode-se distinguir uma intenção comum entre eles: provocar a consolação, tanto entre os que escrevem quanto entre os que leem as cartas. Esse "sentimento", segundo propõe o fundador da Companhia de Jesus, designa

\footnotetext{
[...] todo aumento de fé, esperança e caridade, bem como toda a alegria interna, que chama e atrai paras as coisas celestes e para a salvação da própria pessoa, aquietando-a e pacificando-a em seu Criador e Senhor (LOYOLA, 2009, p. 121).
}

Dessa forma, as narrações de doenças, epidemias e mortes, construídas a partir de procedimentos retóricos e, interpretadas à luz da crença do poder de ação Divino sobre os seres e coisas sensíveis, reafirmavam a conformidade entre a missão jesuítica e 
os desígnios divinos. Assim, mesmo um evento trágico como o perecimento em grande escala dos Tupinambá, poderia constituir o conteúdo de um texto consolativo, desde que concebido a partir de uma crença na orientação providencialista da História.

\section{REFERÊNCIAS}

Fontes primárias

ANCHIETA, José de. Cartas, Informações, Fragmentos Históricos e Sermões do Padre Joseph de Anchieta (1554-1594). Rio de Janeiro: Editora Civilização Brasileira, 1933.

BÍBLIA. Português. Bíblia sagrada. Tradução de Padre Antônio Pereira de Figueredo. Rio de Janeiro: Encyclopaedia Britannica, 1980. Edição Ecumênica.

LOYOLA, Inácio de. Exercícios espirituais. Tradução de R. Paiva, S.J. São Paulo: Edições Loyola. 2009.

AZPILCUETA NAVARRO, João de; e Outros. Cartas avulsas, 1550-1568. Belo Horizonte: Itatiaia; São Paulo: Ed. da USP, 1988.

\section{Fontes secundárias}

ALENCASTRO, Luiz Felipe. O trato dos viventes. São Paulo: Companhia das Letras, 2000 .

ANZOLIN, André Soares. Entre mortes e lembranças: notas sobre as reações dos Tupi à pandemia de varíola de 1562-64. Revista Latino-Americana de História, São Leopoldo, v. 3, n. 12, p. 21-36, dez. 2014. Disponível em: <http://projeto.unisinos.br/rla/index.php/rla/article/viewFile/481/461>. Acesso em: 13 jan. 2015.

ARIÈS, Philippe. História da morte no Ocidente. São Paulo: Ediouro, 2003.

DAHER, Andréa. Escrita e conversão - A gramática tupi e os catecismos bilíngües no Brasil do século XVI. Revista Brasileira de Educação, Rio de Janeiro, n. 8, p. 31-43, maio/jun./jul./ago., 1998.

ECO, Umberto. Tratado geral de semiótica. São Paulo: Perspectiva, 2009.

FAUSTO, Carlos. Os índios antes do Brasil. Rio de Janeiro: Jorge Zahar, 2010. 
FOUCAULT, Michel. As palavras e as coisas: uma arqueologia das ciências humanas. $9^{a}$ ed. Tradução de Salma Tannus Muchail. São Paulo: Martins Fontes, 2007.

HANSEN, Joao Adolfo. A Civilização pela Palavra. In: LOPES, Eliane Marta Teixeira; FARIA FILHO, Luciano Mendes de; VEIGA, Cynthia Greive (Org.). 500 anos de educação no Brasil. Belo Horizonte: Autêntica, 2000.

HANSEN, Joao Adolfo. Alegoria. Construção e Interpretação da Metáfora. São Paulo/Campinas: Hedra/Editora Unicamp, 2006.

HANSEN, Joao Adolfo. O nu e a luz: cartas jesuíticas do Brasil. Revista do Instituto de Estudos Brasileiros, São Paulo, n. 38, 1995.

LE GOFF, Jacques (Org.). As Doenças tem história. Lisboa: Terramar, 1985.

LE GOFF, Jacques; TRUONG, Nicolas. Uma história do corpo na Idade Média. Tradução: Marcos Flamínio Pires. Rio de Janeiro: Civilização Brasileira, 2006.

LUZ, Guilherme Amaral. Carne Humana - A retórica do Canibalismo na América Portuguesa Quinhentista. 2003. Tese (Doutorado em História) - Universidade de Campinas, Programa de Pós-Graduação em Historia, Campinas, 2003.

LUZ, Guilherme Amaral. Os passos da propagação da fé: o lugar da experiência em escritos jesuíticos sobre a América quinhentista. Topoi, Topoi, Rio de Janeiro, v. 4, n. 6, p. 106-127, mar., 2003. Disponível em: <http://www.scielo.br/pdf/topoi/v4n6/2237101X-topoi-4-06-00106.pdf>. Acesso em: 17 jan. 2015.

PÉCORA, Alcir. Cartas à segunda escolástica. In: NOVAIS, Adauto (Org.). A outra margem do Ocidente. São Paulo: Companhia das Letras, 1999.

SINKEVISQUE, E. Três Imagens de Luciano de Samósata no Século XVIII Português. II Colóquio Visões da Antiguidade: Vertentes da Ékphrasis. Faculdade de Filosofia, Letras e Ciências Humanas, Universidade de São Paulo. São Paulo: Ed. USP, 2011.

TODOROV, Tzvetan. A conquista da América: a questão do outro. São Paulo: Martins Fontes, 1993.

TORRES, Magda Maria Jaolino. As Práticas discursivas da Companhia de Jesus e a emergência do "Teatro Jesuítico da missão" no Brasil do século XVI. Tese (Doutorado em História) - Universidade de Brasília, Instituto de Ciências Humanas, Programa de Pós-Graduação em Historia, Brasília, 2006.

VIVEIROS DE CASTRO, Eduardo. O mármore e a murta: sobre a inconstância da alma selvagem. In: VIVEIROS DE CASTRO, Eduardo. A Inconstância da Alma Selvagem e outros ensaios de Antropologia. São Paulo: Cosac \& Naify, 2002. 